\title{
SOCIO LEGAL RESEARCH DALAM ILMU HUKUM
}

Fuad

Fakultas Hukum Universitas Widya Mataram

Email:sangfuad2018@gmail.com

\begin{abstract}
Abstrak
Hukum berperan besar dalam kehidupan manusia khususnya pada masa transisi menuju pembaharuan hukum, begitupun dengan ilmu hukum yang mampu menghadirkan perspektif yang baru. Meskipun dalam perkembangannnya ilmu hukum tidak mampu memberikan data secara lengkap bagi pelaksanaan kekuasaan, namun keberadaan ilmu hukum yang memiliki metode pendekatan yang sistematis, kiranya menjadi hal yag berguna dalam perumusan hukum yang lebih baik. Interaksi yang terjadi antara ilmu hukum dengan ilmu-ilmu sosial lainnya menghadirkan sesuatu yang berbeda dalam konsep hukum dan pada akhirnya menjadi suatu pemahaman dengan perspektif sosiologis. Sehingga pada tataran teoritik, hal tersebut memunculkan sociology of law dan pada tataran filsafat memunculkan sociological jurisprudence. Ilmu hukum yang terus berkembang pada akhirnya menciptakan berbagai aliran, mulai aliran hukum alam (irasional dan rasional), aliran hukum positif (analitis dan murni), aliran utilitarianisme, mazhab sejarah, sociological jurisprudence, pragmatic legal realism, socio legal studies dan aliran hukum kritis. Hal ini menunjukkan proses searching the truth tidak pernah berhenti. Menjelaskan keterkaitan hukum, ilmu hukum, sociological jurisprudence, diperlukan suatu methode research yang tepat dan representatif. Karena melalui research akan ada temuan-temuan baru, berupa pengetahuan yang benar (truth, true, knowledge) dan pada akhirnya digunakan untuk menyelesaikan suatu permasalahan.
\end{abstract}

\section{Kata kunci: Socio, Legal}

\section{A. PENDAHULUAN}

Albert Einstein ${ }^{1}$ menjelaskan bahwa the important thing is never to stop questioning mengetuk alam sadar kita bahwa pada hal apapun hendaknya tak ada kata berhenti untuk bertanya. Karena jalan untuk bertanya akan selalu terbuka, dengan melihat dinamika perkembangan peradaban modern dan segala hal yang ada di dalamnya terus menerus mengikuti kehidupan manusia sampai ke liang lahat. Sehingga bagi manusia modern, ${ }^{2}$ akan

\footnotetext{
${ }^{1}$ Albert Einstein, The Important Thing Is Not to Stop Questioning. Curiosity Has Its Own Reason for Existence, Life Magazine (2 May 1955) Old Man's Advice to Youth: Never Lose a Holy Curiosity' Pages 61-64.

${ }^{2}$ yaitu manusia yang selalu menginginkan perubahan ke arah yang lebih baik, yaitu mengembangkan kehidupannya, memenuhi kebutuhannya, mengembangkan cara-cara pemenuhan kehidupan secara lebih efektif, modern dan efisiensi. Emanuel Prasetyono, Manusia, Ilmu Pengetabuan Dan Kesadaran Diri, Jurnal Orientasi Baru, Vol. 22 No. 2 (2013), hlm. 187,
} 
selalu berupaya melindungi kepentingan-kepentingannya dengan cara apapun, dan disaat yang sama juga mengancam segala yang ada pada manusia itu sendiri.

Pada konteks ini, manusia modern atau yang diistilahkan oleh Harari dalam bukunya Sapiens ${ }^{3}$ disebut sebagai "Homo Sapiens (manusia bijaksana)" akan membutuhkan dukungan dari berbagai hal yang dapat digunakannya baik dalam konteks untuk melindungi kepentingannya secara ekonomi, maupun pada hal-hal lain yang sifatnya untuk melanggengkan eksistensinya sebagai manusia, dimana salah satu piranti yang dapat melindungi hal-hal tersebut satu diantara lainnya adalah apa yang disebut dengan "hukum".

Hukum dan ilmu hukum merupakan hal yang berbeda, namun memiliki keterkaitan yang saling berhubungan. Ilmu hukum tidak identik dengan hukum karena tidak setiap hasil penelitian dan perkembangan ilmu hukum dapat menjadi hukum. Agar dapat menjadi hukum, hasil dari penelitian, kajian maupun pengembangan ilmu hukum harus dituangkan dalam bentuk undang-undang.

Hal ini tidak lain dikarenakan hukum dianggap sebagai seperangkat aturan (norma) yang mengikat siapapun, dapat dipaksakan pelaksanaanya serta memiliki sanksi tegas bagi siapapun yang tidak melaksanakannya. Dalam hal ini keberadaan hukum sesungguhnya dapat memberikan kemanfaatan yang bersifat universal yaitu menciptakan perdamaian dan ketentraman dalam lingkungan masyarakat yang dapat dirasakan secara konkrit oleh seluruh lapisan masyarakat.

Membahas hukum, perkembangan masyarakat maupun kemajuan teknologi merupakan suatu keniscayaan dan berkoherensi antara satu dengan yang lainnya. Pastinya hal-hal tersebut akan terus membayangi kehidupan umat manusia disepanjang perjalanannya di dunia. Misalnya hukum, kelak (pada suatu waktu dimasa depan) tidak akan lagi menjadi bangunan nilai yang bersifat otonom, berdiri sendiri dan terbatas. Ia akan terinfiltrasi atau terpengaruh dengan kondisi sosial masyarakat maupun perkembangan zaman yang dinamis.

Hukum dalam masyarakat mempunyai dua sifat yaitu sifat pasif dan aktif. Sifat pasif hukum dapat dilihat sejauhmana hukum menyesuaikan diri dengan masyarakat. Sedangkan hukum bersifat aktif yaitu sejauhmana hukum dapat berperan aktif dalam menggerakkan dinamika masyarakat menuju perubahan yang terencana. Maka hukum diartikan sebagai alat untuk merubah masyarakat (a tool of social engineering). ${ }^{4}$

Yuval Noah Harari, Sapiens A Brief History of Humankind, diterjemahkan oleh Yanto Musthofa, Sapiens Sejarah Ringkas Umat Manusia dari Zaman Batu Hingga Perkiraan Kepunahannya, Pustaka Alfabet, Jakarta, 2017, hal. 8

4 Achmad Ali, Menguak Tabir Hukum, Suatu Kajian Filosofis dan Sosiologis, PT. Toko Gunung Agung, Cet. II, Jakarta, 2002, hlm. 87-104 
Hukum dan masyarakat merupakan dua gejala yang tidak terpisahkan pada dasarnya hukum juga masyarakat apabila di pandang dari sudut telaah tertentu. Demikian juga halnya dengan kebudayaan; hukum juga merupakan kebudayaan apabila di pandang dari sudut telaah tertentu. ${ }^{5}$

Indonesia merupakan bangsa yang merdeka sehingga menjadi subyek hukum yang merdeka pula. Bangsa Indonesia terlibat penuh dalam aspek penyelenggaraan hukum, mulai pembuatan sampai pelaksanaannya. Hal ini tentunya berbeda dengan kehidupan hukum di masa Hindia Belanda. Pada masa itu bangsa Indonesia tidaklah mempunyai tanggung jawab sepenuhnya dalam masalah perencanaan, pembangunan, pemeliharaan dan penegakan hukumnya. ${ }^{6}$

Maka mulai muncul tuntutan-tuntutan agar hukum dapat dipakai sebagai alat untuk melakukan perubahan atau pengarahan-pengarahan yang sesuai dengan arah politik pembangunan negara. Dengan demikian kini persoalan hukum bukan lagi sekedar persoalan legalitas formal tentang penafsiran serta penerapan pasal undang-undang semestinya, melainkan bergerak ke arah penggunaan hukum yang secara sadar sebagai sarana untuk menyusun tata kehidupan baru. ${ }^{7}$

Peranan hukum dalam kehidupan begitu besar, pun demikian di masa transisi dalam rangka pembaharuan hukum. Ilmu hukum dapat memberikan kemungkinan-kemungkinan baru. Meskipun dalam perkembangannnya ilmu hukum tidak mampu memberikan datadata yang terhimpun lengkap dan tidak memuaskan bagi pelaksanaan kekuasaan, namun dapat dipastikan, ilmu hukum mempunyai metode pendekatan yang kiranya berguna untuk perumusan hukum yang lebih baik.

Pola interaksi yang terjadi antara ilmu hukum dengan ilmu-ilmu lain serta didukung nilai-nilai kemanusiaan yang menghadirkan perspektif berbeda terhadap hukum dari perspektif normatif menjadi pemahaman dengan perspektif sosiologis. Sehingga pada tataran teoritik, menghadirkan sociology of law dan pada tataran filsafat memunculkan sociological jurisprudence.

Terlihat sepintas adanya kesamaan antara sociology of law dengan sociological jurisprudence, dan keduanya juga tidak dapat dipisahkan, tetapi harus dibedakan. Sociology of law adalah bagian atau cabang dari ilmu sosiologi (ilmu-ilmu manusia) yang obyek studinya adalah hukum, sedangkan sociological jurisprudence termasuk cabang ilmu filsafat hukum yang mempelajari hubungan timbal balik antara pengaruh hukum dan masyarakat. Kesamaan

Soerjono Soekanto,dkk, Pendekatan Sosiologi Terhadap Hukum, PT. Bina Aksara, Jakarta, 1988, hlm. 9 Satjipto Rahardjo, Pemanfaatan Ilmu-Ilmu Sosial bagi Pengembangan Ilmu Hukum, Alumni, Bandung, 1977, hlm. 4 Ibid, hlm. 16 
antara sociology of law dan sociological jurisprudence terletak pada optik yang dipakai yaitu samasama menggunakan perspektif sosial dalam memahami hukum.

Ehrlich menjelaskan bahwa pusat bagi perkembangan hukum bukanlah terletak pada badan legislatif, keputusan-keputusan yudikatif atau ilmu hukum, akan tetapi justru terletak dalam masyarakat itu sendiri. Tata tertib dalam masyarakat didasarkan pada peraturanperaturan yang dipaksakan oleh negara. Sementara Roscoe Pound berpendapat, bahwa hukum harus dilihat atau dipandang sebagai suatu lembaga kemasyarakatan yang berfungsi untuk memenuhi kebutuhan-kebutuhan sosial dan adalah tugas ilmu hukum untuk mengembangkan kerangka dari kebutuhan-kebutuhan sosial tersebut dapat dipenuhi.

Pound juga mengarahkan agar ilmu hukum dipelajari sebagai suatu proses (law in action), yang membedakan dengan hukum tertulis (law in books). Pembedaan ini dapat diterapkan pada seluruh bidang hukum yang substantif maupun formil. Ajaran tersebut menonjolkan tentang suatu hukum yang ditetapkan sesuai dengan pola perilaku masyarakat dan dapat diperluas mencakup masalah keputusan-keputusan pengadilan serta pelaksanaannya serta antara isi suatu peraturan dengan efek-efeknya yang nyata. Atas beberapa hal yang telah disebutkan sebelumnya, maka dapat ditelaah terkait posisi socio legal research dalam ilmu hukum.

\section{B. PEMBAHASAN}

\section{Hukum dan Ilmu Hukum}

Pemikiran hukum tidak dapat terlepas dari lingkungan zamannya, ia sering dilihat sebagai suatu jawaban yang diberikan terhadap permasalahan hukum atau menggugat suatu pikiran hukum yang dominan pada suatu waktu. Oleh karena itu, sekalipun ia berkeinginan untuk mengutarakan pikiran secara universal, tetapi alangkah baiknya apabila suatu teori mempunyai latar belakang pemikiran yang mempunyai dasar teori hukum tertentu. ${ }^{8}$

Perkembangan yang terjadi khususnya dalam ilmu pengetahuan sejauh ini tidaklah berlangsung secara mendadak, melainkan terjadi bertahap dan secara simultan berlangsung terus menerus. Perkembangan ilmu pengetahuan muncul dari rasa ingin tahu akan peristiwa-peristiwa yang terjadi di sekitarnya baik bersifat sederhana maupun bersifat lebih kompleks. Rasa ingin tahu yang bersifat sederhana didasari oleh rasa ingin tahu tentang apa (ontologi), rasa ingin tahu yang bersifat kompleks meliputi bagaimana peristiwa tersebut dapat terjadi dan mengapa hal itu terjadi (epistemologi), serta untuk apa peristiwa tersebut dipelajari (aksiologi).

8 Prasetyo dan Abdul Halim, Ilmu Hukum dan Fislafat Hukum, Pustaka Pelajar, Yogyakarta, 2007, hlm. 80 
Ketiga landasan tersebut yaitu ontologi, epistemologi dan aksiologi merupakan ciri spesifik dalam penyusunan pengetahuan termasuk pengetahuan ilmu hukum. Ketiganya saling terkait dan tidak dapat dipisahkan satu dengan lainnya dalam upaya untuk mencapai atau memecahkan peristiwa yang terjadi di lingkungan sekitar. Bila upaya tersebut berhasil, maka diperoleh apa yang dikatakan sebagai ketahuan atau ilmu pengetahuan.

Apa yang dimaksud hukum sebagai ilmu pada dasarnya adalah hal yang unik, rumit sekaligus menarik diperbincangkan khususnya oleh pemerhati hukum. Bahkan sekian abad berkembangnya hukum, hingga saat ini belum ada satu pemahaman yang sama tentang apa pengertian hukum. Pendefinisian tentang hukum memang diperlukan untuk mengetahui apa yang akan dipelajari lebih lanjut tentang hukum itu sendiri, yaitu menunjukkan jalan (open the way), ke arah mana ia akan berjalan. ${ }^{9}$

Memahami hukum sebagai suatu disiplin ilmu yaitu antara lain agar mengarahkan sasaran studinya untuk menghasilkan ilmu tentang kaidah hukum (norm wissenschaft), terhadap pengertian-pengertian hukum yang menghasilkan ilmu tentang pengertian hukum (begriffen wissenschaft) dan terhadap kenyataan-kenyataan hukum yang menghasilkan ilmu tentang kenyataan hukum (sein wissenschaft).

Perkembangan ilmu hukum mengantarkan pada berbagai aliran, mulai aliran hukum alam (irasional dan rasional), aliran hukum positif (analitis dan murni), aliran utilitarianisme, mazhab sejarah, sociological jurisprudence, pragmatic legal realism, socio legal studies dan aliran hukum kritis. Berbagai aliran tersebut menunjukkan bahwa proses mencari hakikat kebenaran tidak pernah berhenti, melainkan terus menerus berproses sebagaimana perubahan yang terjadi dalam masyarakat sebagai basis dari terbentuknya norma-norma hukum. ${ }^{10}$

Pada abad ke-19 dan abad ke-20, terjadi fase perkembangan ilmu yang sangat marak. Berbagai bidang ilmu baru bertambah dengan pesat, misalnya sosiologi, antropologi, ekonomi, psikologi dan informatika. Namun, boleh saja apabil ilmu hukum menyebut dirinya sebagai ilmu yang lebih tua dibanding lainnya.

Penegasan tersebut didapat dari Sunaryati Hartono pada pidato pengukuhan Guru Besar Fakultas Hukum Universitas Padjajaran, bahwa tidak perlu diragukan lagi bahwa hukum adalah bidang ilmu yang sudah sangat tua, bahkan lebih tua dari ilmu-ilmu alam. Hanya menurutnya, pada abad ke-19, oleh aliran empirisme dan ilmu-ilmu murni, hukum

Lili Rasjidi, Filsafat Hukum, Apakah Hukum itu? Remaja Rosdakarya, Bandung, 1993, hlm. 29

10 Esmi Warasih, Penelitian Socio Legal; Dinamika Sejarah dan Perkembangannya, Makalah, Bandung, 2006, hlm. 5 
dianggap tidak ilmiah karena tidak dapat dikualifikasikan dan mengandung nilai-nilai bahkan bersumber dari filsafat moral dan kehidupan kemasyarakatan. ${ }^{11}$

Apa yang dipahami sebagai ilmu hukum secara sederhana merupakan ajaran hukum (rechtsleer), atau disebut dengan dogmatik hukum, yaitu mempelajari hukum positif (ius constitutum). Hukum positif adalah hukum yang berlaku pada suatu tempat, dimana mengatur manusia sebagai makhluk sosial (tertulis, tidak tertulis dan yurisprudensi). Ilmu hukum merupakan realitas kodrati yang eksis dan tertanamkan di setiap hati nurani manusia dan a priori terhadap segala bentuk perilaku manusia. Dalam posisinya sebagai norma kehidupan, maka ilmu hukum merupakan ilmu amaliah. ${ }^{12}$

Hukum sebagai perwujudan nilai mengandung arti bahwa kehadirannya untuk melindungi dan memajukan nilai-nilai yang dijunjung tinggi masyarakat. Eksistensi dan kemampuan hukum lalu diukur seberapa jauh ia telah mewujudkan keadilan tersebut. Dengan demikian, moral keadilan telah menjadi dasar untuk mensahkan kehadiran dan bekerjanya hukum. ${ }^{13}$

Hukum juga akan selalu terwujud dalam keputusan-keputusan yang berisi banyak pertimbangan lainnya, seperti moral, kondisi sosial, kemasyarakatan, kultural dan sebagainya yang menjadi elemen dalam menyusun penilaian. Sehingga elemen penyusun keputusan hukum akan menjadi lentur dan adaptif dalam merespon setiap hal yang terjadi disekitarnya.

\section{Ilmu Hukum dan Sociological Jurisprudence}

Sociological jurisprudence juga disebut sebagai aliran hukum fungsional (functional anthropological), ${ }^{14}$ memiliki pengaruh yang cukup signifikan dalam penerapan hukum di Indonesia khususnya pada upaya pembangunan hukum sebagai salah satu aspek yang bersifat praktis. Namun, selain pengaruh aliran sociologial jurisprudence, jauh sebelum itu pengaruh aliran positivisme hukum dan mazhab sejarah sudah lebih dahulu ada sejak zaman kolonial.

Sociological jurisprudence dikatakan sebagai salah satu aliran dari berbagai pendekatan, dimana tumbuh dan berkembang di Amerika yang dipelopori oleh Roscoe Pound dengan karya-karyanya yang terkenal seperti Scope and purpose of sosiological jurisprudence (1912), Outline of Lectures on Jurisprudence (1903), The Spirit of Common Law (1921), An Introduction to the

11 Sunaryati Hartono, Pembinaan Hukum Nasional Dalam Suasana Globalisasi Masyarakat Dunia, Pidato Pengukuhan Jabatan Guru Besar Pada Fakultas Hukum Universitas Pajajaran di Bandung, pada tanggal 1 Agustus 1991, hlm. 15

12 Isharyanto, Teori Hukum, Suatu Pengantar Dengan Pendekatan Tematik, Penerbit WR, Yogyakarta, 2016 hlm. 1

13 Satjipto Rahardjo, Hukum dan Prilaku, Jakarta: PT. Kompas Media Nusantara, Jakarta, 2009, hlm. 66

14 Dardji Darmodihardjo dan Sidharta, Pokok-pokok. Filsafat Hukum, Gramedia Pustaka Utama, Jakarta, 1995, hlm. 110-111 
Philosophy of Law (1922), The Task of Law (1944), Interpretation of Legal History (1923), dan lain-lain. Sedangkan tokoh lainnya adalah Benjamin Cordozo dan Kantorowics.

Terdapat perbedaaan antara sociological jurisprudence dengan sosiologi hukum, dimana sociological jurisprudence yang merupakan aliran filsafat hukum mempelajari pengaruh timbal balik antara hukum dan masyarakat, sedangkan sosiologi hukum adalah cabang sosiologi yang mempelajari pengaruh masyarakat kepada hukum dan sejauh mana gejala-gejala yang ada dalam masyarakat itu dapat mempengaruhi hukum tersebut disamping juga diselidiki sebaliknya pengaruh hukum terhadap masyarakat. Yang terpenting adalah bahwa sociological jurisprudence cara pendekatannya bermula dari hukum ke masyarakat sedangkan sosiologi hukum sebaliknya dari masyarakat ke hukum. ${ }^{15}$

Pengaruh aliran (konsepsi) hukum fungsional baru berkembang di Indonesia sekitar tahun 1970-an terutama pada masa Orde Baru. Mochtar Kusumaatmaja mengadaptasi sociological jurisprudence dalam rangka pembangunan hukum di Indonesia dan sebagai hasilnya adalah suatu pemikiran filosofis yang dikenal dengan sebutan "Konsepsi Hukum Sebagai Sarana Pembaharuan Masyarakat." Bahkan, konsepsi hukum ini secara resmi menjadi landasan filosofi kebijakan pembangunan hukum Indonesia seperti tertuang dalam Ketetapan MPR Nomor IV Tahun $1973 .^{16}$

Para ilmuan sosial yang mulai mempelajari hukum memberikan makna yang lebih luas terhadap hukum. Dapat dikatakan bahwa adanya dimensi sosiologis, ekonomi, psikologi, dan lain-lain dari hukum itu tidak disebabkan oleh munculnya disiplin ilmu-ilmu sosial tersebut, melainkan dimensi itu telah ada sejak adanya hukum. ${ }^{17}$

Jika melihat kecenderungan dalam ilmu hukum, nampak ada dua yang sedang terjadi;

1) Ilmu hukum terbagi ke dalam berbagai bidang yang seolah-olah masing-masing berdiri sendiri;

2) Ilmu hukum menumpang pada bidang ilmu lain, sehingga seolah-olah bukan merupakan suatu ilmu yang berdiri sendiri.

Kecenderungan pertama nampak dengan terbentuknya ilmu hukum ke dalam ilmu yang bersifat normatif, ilmu yang bersifat empiris dan ilmu yang bersifat filosofis. Kecenderungan kedua tampak dengan semakin kentalnya sikap yang menganalogikan ilmu hukum dengan sosiologi hukum dan antropologi hukum. ${ }^{18}$ Kecenderungan ilmu hukum

15 Lili Rasjidi, Pengantar Filsafat Hukum, Mandar Maju, Bandung, 1992, hlm. 47

16 Lili Rasjidi dan Ira Thania Rasjidi, Pengantar Filsafat Hukum, Mandar Maju, Bandung, 2002, hlm. 65

17 Satjipto Rahardjo, Ilmu Hukum; Pencarian, Pembebasan, dan Pencerahan, Muhammadiyah University Press, Surakarta, 2004, hlm. 32

18 Sugijanto Darmadi, Kedudukan Ilmu Hukum Dalam Ilmu dan Filsafat, Mandar Maju, Bandung, 1998, hlm. 58 
tersebut telah mengurangi kemampuan ilmu hukum dalam perkembangannya dan dalam menghadapi masalah-masalahnya, hal ini karena adanya kelemahan yang dijumpai dalam ilmu hukum yang murni secara teoritis semata-mata maupun ilmu hukum yang terapan semata-mata.

Hukum merupakan objek kajian dari ilmu hukum, sebab itu kebenaran hukum yang hendak diungkap oleh ilmu hukum mendasarkan pada sifat-sifat yang melekat pada hakekat hukum. Membicarakan hakikat hukum secara tuntas, maka perlu diketahui tiga tinjauan yang mendasarinya, yaitu tinjauan ontologi, epistimologi dan aksiologi. ${ }^{19}$

Tinjauan ontologi secara umum ada 3 (tiga) hal yang dapat dipelajari dari hukum yaitu;

1) nilai-nilai hukum seperti keadilan, ketertiban, kepastian hukum dan lain-lain;

2) kaidah-kaidah hukum berupa kaidah yang tertulis maupun tidak tertulis, kaidah yang bersifat abstrak maupun nyata;

3) perilaku hukum atau dapat juga disebut kenyataan hukum atau peristiwa hukum. Secara umum filsafat hukum mengkaji nilai-nilai hukum, sosiologi hukum, antropologi hukum, psikologi hukum dan lain-lain serta mengkaji perilaku hukum. Sedangkan kaidah hukum dikaji oleh bidang yang disebut normwissenschaf atau ilmu tentang kaidah.

Tinjauan epistimologi menjelaskan bahwa ilmu hukum sebagai ilmu bertujuan untuk mencari kebenaran atau tepatnya keadilan yang benar. Untuk mencari keadilan yang benar, maka ditentukan cara mencarinya yaitu disebut "metode". Metode ilmu hukum ditentukan oleh aspek ontologis dan aksiologis dari hukum, juga dengan konsep metode dan ilmu yang bersifat universal. Artinya untuk bidang atau jenis ilmu manapun adalah sama, tetapi pengaruh dari obyek suatu ilmu tentu tidak dapat dihindari. Sehingga hakikat hukum dan fungsinya dalam praktik tak dapat dihindari berpengaruh dalam menentukan metode yang digunakan ilmu hukum, dimana pada waktu saat ini, berkembang pada metode normatif, sosiologis dan filosofis.

Tinjauan aksiologis, menjelaskan bahwa ilmu hukum bersifat dinamis yaitu memiliki peran dan fungsi yang khas di banding bidang-bidang hukum lainnya. Secara aksiologis, peran dan fungsi ilmu hukum antara lain;

1) Ilmu hukum berpengaruh dalam pembentukan hukum melalui penyusunan perundang-undangan

2) Ilmu hukum berpengaruh dalam praktek hukum atau pelaksanaan hukum

19 Ibid, hlm. 59-69 
3) Ilmu hukum berpengaruh dalam pendidikan hukum

4) Ilmu hukum akan berpengaruh atas perkembangan bidang-bidang yang lain

5) Ilmu Hukum berusaha untuk mengadakan sistematisasi bahan-bahan yang tercerai berai disatukan dalam suatu susunan yang bersifat komprehensif.

Sebagai upaya mengembangkan ilmu hukum sebagai ilmu yang bersifat mandiri, perlu diperoleh kejelasan terkait tempat kedudukan ilmu hukum dalam jajaran dunia keilmuan, apakah termasuk dalam jajaran ilmu normatif atau apa yang dinamakan "sollenwissenschaft", ataukah termasuk dalam ilmu-ilmu sosial atau ilmu empiris atau yang disebut "seinwissenschafe' baik bersifat monodisipliner maupun interdisipliner atau juga mencakup, baik ilmu yang bersifat normatif dan sekaligus empiris, sehingga menjadi sebuah ilmu yang unik yaitu mempunyai dua wajah. ${ }^{20}$

Penegasan ini diperlukan untuk menjawab dari sudut pandang mana hukum hendak dilihat. Bila hukum dilihat sebagai seperangkat aturan yang bersifat abstrak dan berada dalam dunia nilai, maka ilmu yang mempelajarinya dikualifikasikan sebagai ilmu normatif atau ilmu dogmatik. Namun, bila hukum dilihat semata-mata sebagai sebuah institusi sosial yang secara riil berada dalam masyarakat, maka kajian ilmu hukum tersebut bersifat ilmu empiris.

Abdul Hamid Saleh Attamimi dalam pidato pengukuhan Guru Besar Fakultas Hukum Universitas Indonesia menegaskan bahwa ilmu hukum tidak pernah menjadi ilmu hukum normatif murni dan tidak pernah menjadi ilmu sosial murni karena hukum dapat berasal dari sollen sein dan dapat pula berasal dari sein sollen. ${ }^{21}$

Maka obyek ilmu hukum yang berupa legislasi maupun kebiasaan, sama halnya dengan obyek fisika yang berasal dari fenomena alamiah, begitu juga fakta-fakta sejarah seni dan kreasi sang seniman. Jadi, menurut Karl Garries, dkk., tidak diragukan lagi bahwa ilmu hukum positif yang oleh Visser Hooft dinamakan praktische rechtswtenschap (ilmu hukum praktis) baik dari obyek studi dan metodenya adalah pengetahuan yang sistematik, maka ilmu hukum sama seperti ilmu-ilmu lainnya. ${ }^{22}$

Mengutip yang disampaikan Satjipto Rahardjo, bahwa ilmu hukum mempunyai hakikat interdisipliner. Hakikat ini diketahui dan digunakannya berbagai disiplin ilmu pengetahuan untuk membantu menerangkan berbagai aspek dari hukum yang diketahui ternyata tidak dapat dijelaskan dengan baik tanpa memanfaatkan disiplin-disiplin ilmu

20 Abdurrahman, Ilmu Hukum, Teori Hukum, dan Ilmu Perundang-Undangan, PT. Citra Aditya Bakti, Bandung, 1994, hlm. 155-156

21 Abdul Hamid Saleh Attamimi, Teori Perundang-Undangan Indonesia, Pidato Pengukuhan Guru Besar Fakultas Hukum Universitas Indonesia, di Jakarta pada tanggal 25 April 1992, hlm. 18

22 I Dewa Gede Atmadja, Menyoal Filsafat Ilmu, Jurnal Notariil, Vol. 2, No. 2, tanpa tahun hlm. 120 
pengetahuan, seperti politik, antropologi, ekonomi dan lain sebagainya. Antropologi misalnya membantu menjelaskan tentang kerja dari hukum itu yang tidak dapat dijelaskan dari keseluruhan kehidupan masyarakat sebagai satu kesatuan budaya. ${ }^{23}$

Lebih lanjut, dalam pidato pengukuhan Guru Besar Fakultas Hukum Universitas Diponegoro; Satjipto Rahardjo menyebut dua hal tentang hukum yaitu "optik preskriptif” dan “optik deskriptif'. Dalam optik preskriptif hukum dilihat sebagai suatu cara yang harus dijalankan, sedangkan optik deskriptif menjelaskan fenomena hukum dalam masyarakat yaitu menelaah hukum secara sosial. ${ }^{24}$ Namun dalam pembahasan selanjutnya ia lebih cenderung berkiprah pada optik deskriptif atau juga disebutnya sebagai telaah sosial tentang hukum. Menurut pendapatnya relevansi sosial dari optik deskriptif terhadap hukum di Indonesia saat ini cukup besar dengan menggunakan telaah tersebut, sehingga dapat dijelaskan atau dijawab secara sistematis berbagai persoalan yang timbul yang tidak dapat dijelaskan secara demikian itu apabila menggunakan optik preskriptif. ${ }^{25}$

\section{Socio Legal Research dalam Ilmu Hukum}

Penelitian dalam bahasa Inggris disebut dengan istilah research pada hakikatnya merupakan sebuah upaya pencarian. Lewat penelitian (research) orang mencari (search) temuan-temuan baru, berupa pengetahuan yang benar (truth, true, knowledge) yang dapat dipakai untuk menjawab suatu pertanyaan atau untuk memecahkan suatu masalah. ${ }^{26}$ Dengan kata lain, penelitian (research) merupakan upaya pencarian yang amat bernilai edukatif, yaitu melatih untuk selalu sadar bahwa banyak hal di dunia yang belum diketahui dan dapat mencoba menemukannya. Apa yang sudah ditemukan dan diketahui tetap bukan kebenaran yang mutlak, sehingga masih perlu diuji kembali. ${ }^{27}$

Untuk mencari dan menemukan tentu ada caranya. Cara itu disebut "metode". Metode berasal dari kata Yunani "methodos" atau dari kata latin "methodus" yang berarti upaya untuk mencari pengetahuan atau ilmu memeriksa secara nasional (atau meneliti) dan cara melakukan kegiatan penelitian. ${ }^{28}$ Sedangkan perbincangan keilmuan tentang metode disebut metodologi.

J.J.H. Bruggink menegaskan bahwa tuntutan keilmuan suatu penelitian ilmiah dalam ilmu hukum setidaknya memuat tiga hal, yaitu sebagai berikut: ${ }^{29}$

23 Satjipto Rahardjo, Imu Hukum, Op.Cit, hlm. 7

24 Satjipto Rahardjo, Manfaat Telaah Sosial Terhadap Hukum, Pidato Pengukuhan Guru Besar Fakultas Hukum Universitas Diponegoro, di Semarang pada tanggal 13 Desember 1980, hlm. 1-3

25 Ibid., hlm. 8

26 M. Syamsudin, Operasionalisasi Penelitian Hukum, PT. Rajawali Press, Jakarta, 2007, hlm. 21

27 Amiruddin dan Zainal Asikin, Pengantar Metode Penelitian Hukum, PT. Rajawali Press, Jakarta, 2004, hlm. 19

28 Sunaryati Hartono, Penelitian Hukum di Indonesia Pada Akhir Abad Ke 20, Alumni, Bandung, 1994, hlm. $105-106$

29 J.J.H Bruggink, Refleksi Tentang Hukum, PT. Citra Aditya Bakti, Bandung, 1999, hlm. 217-218 
1. Ilmuan hukum harus mengemukakan dengan cara kerja ajeg dan mengetahui mana yang hendak digunakan untuk membentuk teorinya.

2. Ia mempersentasikan cara kerjanya sedemikian rupa sehingga orang lain dapat mengkaji hasil-hasil dari teorinya dengan bantuan cara kerja itu; dan

3. Ilmuan hukum harus mempertanggungjawabkan (memberikan penjelasan rasional) mengapa memilih cara kerja itu.

Soetandyo Wignyosoebroto membedakan lima tipe kajian hukum berdasarkan perbedaan konsep hukum. Perbedaan tipe kajian ini menyebabkan juga perbedaan dalam pemilihan dan penggunaan metode kajiannya, diungkapkannya dalam rumus $M=f(K)$, yakni metode adalah fungsi konsep. Lima tipe kajian tersebut adalah: ${ }^{30}$

a. Tipe-kajian filsafat hukum yang bertolak dari pandangan bahwa hukum adalah asasasas kebenaran dan keadilan yang bersifat kodrati dan berlaku universal. Tipe-kajian ini berorientasi kefilsafatan, dan menggunakan metode logika-deduksi yang bertolak dari premis normatif yang diyakini bersifat self-eviden.

b. Tipe-kajian ajaran hukum murni yang mengkaji law as it is written in the books, yang bertolak dari pandangan bahwa hukum adalah norma-norma positif di dalam sistem perundang-undangan hukum nasional. Berorientasi positivistis dan menggunakan metode doktrinal bersaranakan logika deduksi untuk membangun sistem hukum positif.

c. Tipe-kajian american sociological jurisprudence yang mengkaji law as it is decided by judges through judicial processes, yang bertolak dari pandangan bahwa hukum adalah apa yang diputuskan oleh hakim in concreto dan tersistematisasi sebagai judge made law. Berorientasi behavioral dan sosiologik, serta menggunakan metode doktrinal dan non doktrinal bersaranakan logika induksi untuk mengkaji "court behaviourt".

d. Tipe-kajian sosiologi hukum yang mengkaji law as it is in society, yang bertolak dari pandangan bahwa hukum adalah pola perilaku sosial yang terlembaga dan eksis sebagai variabel sosial yang empirik, berorientasi struktural dan menggunakan metode sosial/ non doktrinal dengan pendekatan struktural/ makro dan umumnya kuantitatif.

e. Tipe-kajian sosiologi dan/ atau antropologi hukum yang mengkaji law as it is in (buman) actions, yang bertolak dari pandangan bahwa hukum adalah manifestasi makna-makna simbolik pelaku sosial sebagaimana tampak dalam interaksi antar-mereka. Berorientasi

30 Soetandyo Wignyosoebroto, Penelitian Hukum; Sebuah Tipologi, Jurnal Masyarakat Indonesia, Tahun I, No. 2, 1974, hlm. 89-98. Dikutip oleh Bernard Arief Sidharta, Refleksi tentang Struktur Ilmu Hukum, Mandar Maju, Bandung, 2000, hlm. 158-159 
simbolik interaksional dan menggunakan metode sosial/ non-doktrinal dengan pendekatan interaksional/ makro dengan analisis kualitatif.

Tipe kajian hukum (a), (b) dan (c) termasuk tipe penelitian hukum yang mengacu pada konsep hukum sebagai kaidah yang disebut penelitian normatif. Metodenya disebut metode doktrinal normologik yang bertolak dari kaidah sebagai ajaran yang mengkaidahi perilaku. Tipe kajian hukum yang mengacu pada konsep hukum sebagai kaidah dan metode doktrinal adalah metode yang digunakan dalam kegiatan pengembangan teori hukum dan ilmu hukum. Tipe kajian hukum (d) dan (e) termasuk penelitian hukum yang mengacu pada konsep hukum sebagai proses atau perilaku yang berulang setiap kali terjadi hal yang sama atau disebut penelitian sosial atau penelitian empirik. Disini hukum tidak di pandang sebagai kaidah melainkan sebagai regularitas atau keajegan perilaku yang berpola dengan metodenya yang disebut non doktrinal normologik. Metode ini digunakan dalam penelitian sosial terhadap kaidah hukum yang digunakan dalam disiplin hukum yang bersifat empiris, yakni sosiologi hukum dan antropologi hukum.

Karya terbarunya Soetandyo Wignjosoebroto berjudul "Hukum, Paradigma, Metode dan Dinamika Masalahnya" mempertegas wacana penelitian hukum pada empat kelompok besar dengan yaitu: ${ }^{31}$

I. Studi tentang hukum sebagai suatu model institusi

a. Kaidah sosial, kaidah hukum, dan kaidah hukum negara.

b. Sosialisasi hukum sebagai proses kontrol sosial I.

c. Ancaman dan penerapan sanksi sebagai proses kontrol sosial II.

d. Lembaga pengada, penegak dan penerapan hukum dan tempat serta peranannya dalam sistem politik.

e. Profesi hukum dan pendidikan hukum.

II. Studi tentang hukum sebagai proses konflik yang dinamis

a. Ketaatan dan keefektifan hukum.

b. Stratifikasi dan keefektifan sanksi hukum.

c. Proses legislasi: antara regulasi dan deregulasi.

d. Proses peradilan dan perilaku yudisial dalam kerangka upaya penyelesaian konflik.

e. Hukum dan revolusi.

f. Hak-hak asasi manusia dan konstitusionalisme dalam kehidupan hukum dan politik.

31 Soetandyo Wignjosoebroto, Hukum, Paradigma, Metode dan Dinamika Masalahnya, Elsam dan Humma, Jakarta, 2002, hlm. 56-58 
III. Studi tentang hukum di tengah-tengah konteks perubahan

a. Hukum sebagai realitas dalam proses reformasi sosial: dari hukum rakyat ke hukum nasional yang positif.

b. Hukum sebagai realitas dalam proses transaksi politik dalam kehidupan nasional: modernisasi hukum.

c. Hukum sebagai realitas dalam proses transplantasi cultural.

d. Hukum sebagai realitas dalam proses transformasi ekonomi-bisnis: Menuju global market.

IV. Metode-metode dalam kajian sosiologi hukum kontemporer

a. Teori-teori struktur dalam sosiologi hukum dan metodenya yang klasik-kuantitatif.

b. Teori-teori aksi dalam sosiologi hukum dan metodenya yang kualitatif.

c. Variasi metode kualitatif dari teori agency dalam sosiologi hukum.

Jika dicermati secara seksama, berbagai jenis dan kategorisasi penelitian hukum yang dimaksud dapat dikelompokkan dalam beberapa kelompok ilmu: sosiologi hukum (sociology of law), sociological jurisprudence, ilmu politik (political science) ketiganya menggunakan paradigma metode penelitian ilmu-ilmu sosial yang masuk dalam kelompok ilmu empiris dan ilmu hukum normatif (jurisprudence) yang masuk dalam kelompok ilmu praktis. Pengelompokan ini cenderung mempertegas pernyataan bahwa hukum adalah ilmu bersama (rechts is mede wetenschap) dan hukum menjadi objek kajian berbagai disiplin dan kelompok ilmu.

Melihat keanekaragaman studi hukum, Satjipto Rahardjo menegaskan bahwa bagi setiap orang dapat menggunakan metode yang sesuai dengan pilihannya, asalkan pilihan itu diterapkan secara konsekuen. ${ }^{32}$ Misalnya, apabila memilih melihat hukum sebagai perwujudan dari nilai-nilai tertentu, maka pilihan itu akan membawa pada konsekuensi penggunaan metode yang bersifat idealis. Sedangkan, jika memilih melihat hukum sebagai suatu sistem peraturan-peraturan yang abstrak, maka perhatiannya akan berpusat pada hukum sebagai suatu lembaga yang benar-benar otonom dan konsekuensinya adalah penggunaan metode normatif atau juga disebut normatif analitis dan bagi yang memahami hukum sebagai alat mengatur masyarakat, maka pilihannya akan jatuh pada penggunaan metode sosiologis. ${ }^{33}$

\section{PENUTUP}

Satjipto Rahardjo, Ilmu Hukum, Op.Cit, hlm. 5

33 Ibid, hlm. 5-6. 
Ilmu Hukum memiliki ciri interdisipliner. Ini tidak berarti bahwa ilmu sebagai cabang pengetahuan yang berdiri sendiri memiliki ciri khas yang berbeda. Hukum sebagai ilmu yang mengandung dimensi normatif dan berhubungan dengan dunia pemikiran menuntut kita untuk memasukkannya ke dalam ilmu normatif, sehingga jenis penelitiannya disebut sebagai penelitian normatif dengan metode yang disebut metode ajaran, karena bertolak dari kaidah sebagai ajaran yang mengkaidahkan pada perilaku. Sebaliknya jika melihat dari sisi yang lain, maka ilmu hukum juga termasuk dalam dimensi empiris, sehingga mau tidak mau kita akan memasukkannya ke dalam ilmu sosial. Sedangkan jenis penelitian tersebut yaitu "penelitian empiris" atau socio legal research. Metode ini disebut dengan metode "non doktrinal" karena menggunakan kaidah hukum dalam penelitian sosial, dan kaedah hukumnya pada dasarnya bersifat empiris.

Hukum pada prinsipnya mengandung aspek cita dan realita atau aspek normatif dan aspek empiris. Kajian tentang hukum tidak mungkin lepas dari kaitannya dengan masyarakat, sehingga sulit bagi ilmu hukum untuk dilihat terlepas dari ilmu-ilmu sosial lainnya. Oleh karena itu, sehingga dapat dipahami, bahwa socio legal research merupakan bagian dari ilmu hukum.

\section{DAFTAR PUSTAKA}

Achmad Ali, Menguak Tabir Hukum, Suatu Kajian Filosofis dan Sosiologis, PT. Toko Gunung Agung, Cet. II, Jakarta, 2002

Abdul Hamid Saleh Attamimi, Teori Perundang-Undangan Indonesia, Pidato Pengukuhan Guru Besar Fakultas Hukum Universitas Indonesia, di Jakarta pada tanggal 25 April 1992.

Abdurrahman, Ilmu Hukum, Teori Hukum, dan Ilmu Perundang-Undangan, PT. Citra Aditya Bakti, Bandung, 1994.

Amiruddin dan Zainal Asikin, Pengantar Metode Penelitian Hukum, PT. Rajawali Press, Jakarta, 2004.

Barus, Zulfadli, Analisis Filosofis Tentang Peta Konseptual Penelitian Hukum Normatif Dan Penelitian Hukum Sosiologis, Jurnal Dinamika Hukum, 2013

Bernard Arief Sidharta, Refleksi Tentang Struktur Ilmu Hukum, Mandar Maju, Bandung, 2000. 
Dardji Darmodihardjo dan Sidharta, Pokok-pokok Filsafat Hukum, Gramedia Pustaka Utama, Jakarta, 1995

Emanuel Prasetyono, Manusia, Ilmu Pengetahuan Dan Kesadaran Diri, Jurnal Orientasi Baru, Vol. 2 No. 22, 2013

Esmi Warasih, Penelitian Socio-Legal; Dimanaka Sejarah dan Perkembangannya, Makalah, Bandung, 2006

Einstein, Albert, The Important Thing Is Not to Stop Questioning. Curiosity Has Its Own Reason for Existence, LIFE Magazine (2 May 1955) Old Man's Advice to Youth: Never Lose a Holy Curiosity, 1955

I Dewa Gede Atmadja, Menyoal Filsafat Ilmu, Jurnal Notariil, Vol. 2, No. 2, tanpa tahun

Isharyanto, Teori Hukum, Suatu Pengantar Dengan Pendekatan Tematik, Penerbit WR, Yogyakarta, 2016

J.J.H Bruggink, Refleksi tentang Hukum, PT. Citra Aditya Bakti, Bandung, 1999.

Lili Rasjidi, Pengantar Filsafat Hukum, Mandar Maju, Bandung, 1992, hlm. 47 , Filsafat Hukum, Apakah Hukum itu? Remaja Rosdakarya, Bandung, 1993 dan Ira Thania Rasjidi, Pengantar Filsafat Hukum, Mandar Maju, Bandung, 2002

M. Syamsudin, Operasionalisasi Penelitian Hukum, PT. Rajawali Press, Jakarta, 2007

Prasetyo dan Abdul Halim, Ilmu Hukum dan Fislafat Hukum, Pustaka Pelajar, Yogyakarta, 2007

Satjipto Rahardjo, Pemanfaatan Ilmu-Ilmu Sosial bagi Pengembangan Ilmu Hukum, Alumni, Bandung, 1977 , Manfaat Telaah Sosial Terhadap Hukum, Pidato Pengukuhan Guru Besar pada Fakultas Hukum Universitas Diponegoro Di Semarang pada tanggal 13 Desember 1980 Ilmu Hukum, PT. Citra Aditya Bakti, Bandung, 2000 , Ilmu Hukum; Pencarian, Pembebasan, dan Pencerahan, Muhammadiyah University

Press, Surakarta, 2004 , Hukum dan Prilaku, Jakarta: PT. Kompas Media Nusantara, Jakarta, 2009

Soerjono Soekanto, dkk, Pendekatan Sosiologi Terhadap Hukum, PT. Bina Aksara, Jakarta, 1988. , dan Purnadi Purbacaraka, Sendi-Sendi Ilmu Hukum dan Tata Hukum, Alumni, Bandung, 1986.

Soetandyo Wignyosoebroto, Hukum, Paradigma, Metode, dan Dinamika Masalabnya, Elsam dan Humma, Jakarta, 2002

Sugijanto Darmadi, Kedudukan Ilmu Hukum Dalam Ilmu dan Filsafat, Mandar Maju, Bandung, 1998 
Sunaryati Hartono, Pembinaan Hukum Nasional Dalam Suasana Globalisasi Masyarakat Dunia, Pidato Pengukuhan Jabatan Guru Besar pada Fakultas Hukum Universitas Pajajaran Bandung, pada tanggal 1 Agustus 1991 , Penelitian Hukum di Indonesia Pada Akbir Abad Ke 20, Alumni, Bandung, 1994 Yuval Noah Harari, Sapiens A Brief History of Humankind, diterjemahkan oleh Yanto Musthofa, Sapiens Sejarah Ringkas Umat Manusia dari Zaman Batu Hingga Perkiraan Kepunahannya, Pustaka Alfabet, Jakarta, 2017 